\title{
TEST RESULTS OF CO-SEEDING TECHNOLOGY FOR FORAGE PRODUCTION IN MIX-CROPP FARMING SYSTEM
}

\author{
Viktor Melnyk, Mikola Artiomov, Mykhailo Tsyganenko, Oleksandr Romanashenko, Oleksandr Anikeev \\ Kharkiv Petro Vasylenko National Technical University of Agriculture, Ukraine \\ viktor_melnik@ukr.net, artiomovprof@ukr.net,cmixail@ukr.net, romanashenko.a@gmail.com, \\ anikeev55@ukr.net
}

\begin{abstract}
The part of the chronological range of cropping systems of current interest includes Mini-Till, No-Till and Strip-Till, the latter being now in a state of development and widespread distribution. Through the research into the evolution of agriculture, it has been established that Strip-Till will be replaced by a Mix-Cropp system, its main feature being the dominance of mixed crops. Rot-Mix will replace Mix-Cropp. The former is based on the use of crop rotations of mixed crops. By analyzing modern agricultural production and the trends of its development, it has been established that mixed sowing technologies are already in demand. In particular, it is necessary to develop a system of machines for mixed sowing of soybeans with corn for fodder purposes. As a result of cooperation between the University and JSC 'Elvorti', a prototype of the Vega-8w Profi seeder was manufactured, which implements the possibility of independent sowing of seeds of two crops in one row. The purpose of the work is field testing of a prototype of the Vega-8w Profi seeder when performing mixed sowing of forage crops of corn and soybeans to obtain an increase in the yield and quality of the resulting products, in forage production - primarily to improve the quality of forage. The tests showed that the total yield of silage mass of soybeans with corn, grown together, is guaranteed to be higher than in the case of separate growing of the crops. The quality of the experimental silage, for a number of indicators, is also higher than that of silage without soybeans, or silage obtained by adding soybeans grown separately. The productivity of cattle in terms of both meat and milk in the case of feeding the animals on the experimental silage also exceeded the control. Today, the work on improving the system of machines and technologies for co-cultivation of soybeans with corn for fodder purposes as the technology of the upcoming farming system Mix-Cropp continues.
\end{abstract}

Keywords: mixed sowing, feed crops, corn, soy, seeder.

\section{Introduction}

Research plans of any scientific institution are usually formed on the base of the experience of the scientists and regulations and recommendations of appropriate institutions. In order not to make a mistake in the relevance of the selected areas of research, our university conducted a forecast of the future in agriculture [1].

It has been established that the chronological series of evolution of the Mini-Till, No-Till, Strip-Till farming systems will be continued by the next Mix-Cropp farming system, the dominance of mixed crops being the main feature. Mix-Cropp will be replaced by Rot-Mix, which is based on the use of crop rotations between mixed crops [2].

With the development of civilization, the agrarian direction of crop production, animal husbandry and fodder production was inevitably developed [3]. As a result, co-cultivation of fodder plants has been borrowed from nature, where both herbaceous and arboreal plants can exist when adapted to natural conditions and to each other. Grass and tree vegetation is known to grow most often in the form of plant communities - phytocenoses, which are better adapted to the conditions of the place where they grow. In the case of successful plant selection, sufficient moisture and nutrients, the productivity of mixtures is not lower than that of single-species crops, and often even exceeds it. Co-cultivation of fodder and forage crops is one of the urgent problems of fodder production. With the revival of fodder production, and the interest in these crops is growing. This is true for both perennial and annual forage crops [4].

When growing fodder crops both in Ukraine and abroad, mixed sowing and direct drilling of these crops have been used for a long time. This allows, on the one hand, more efficient use of sown areas, and, on the other hand, it increases the yield per unit of area of crops. This is especially true of mixed cereals with legumes, because such mixtures provide the highest protein content and protein yield per unit of area. Green mass of legumes contains a lot of minerals and vitamins, which increases the digestibility of feed. Corn silage harvested in the phase of milk-wax ripeness of grain contains only 55$60 \mathrm{~g}$ of digestible protein in one feed unit, which is significantly less than the zootechnical norm (100$110 \mathrm{~g}$ for cattle). To improve this ratio, mixed sowing of corn with soybeans is organizationally and economically most profitable [4]. 
According to detailed studies [5-9], mixed sowing of corn and soybeans are most effective if they are sown in one row. Until now, due to the lack of appropriate technical support, this has been quite difficult to do. Therefore, for mixed sowing, various schemes were used, in which rows of corn alternated with rows of soybeans [5]. Under this scheme, the amount of the main crop was halved, which significantly affected the overall yield of the final product. There were such crops when corn was sown with one machine, and soybean was sown with another one in parallel, at an angle or even across prior sowing corn. All schemes of mixed sowing were energy-intensive and did not allow to perform interrow tillage, spraying of chemicals being the only method.

The main purpose of the research is to evaluate the modern technical and technological possibilities of application the advantages of the technology of mixed crops of soybeans with corn for fodder purposes in cattle breeding.

\section{Materials and methods}

Similar technical solutions already exist in Europe [10] and in North America [11]. The design of such seeders places the seeds of plants in a double row with an offset of the seed interval in the adjacent row by half the interval, i.e. in a checkerboard pattern to increase the feeding area of each plant, and is used mainly for row crops for grain.

As a result of cooperation between the scientists of KhNTUSA and specialists of the private jointstock company (PJSC) "Elvorti" the schematic diagram of the specialized seeder for mixed sowing of forage crops was developed and the prototype of the seeder "Vega-8w Profi" by "Elvorti" was made (Fig. 1).

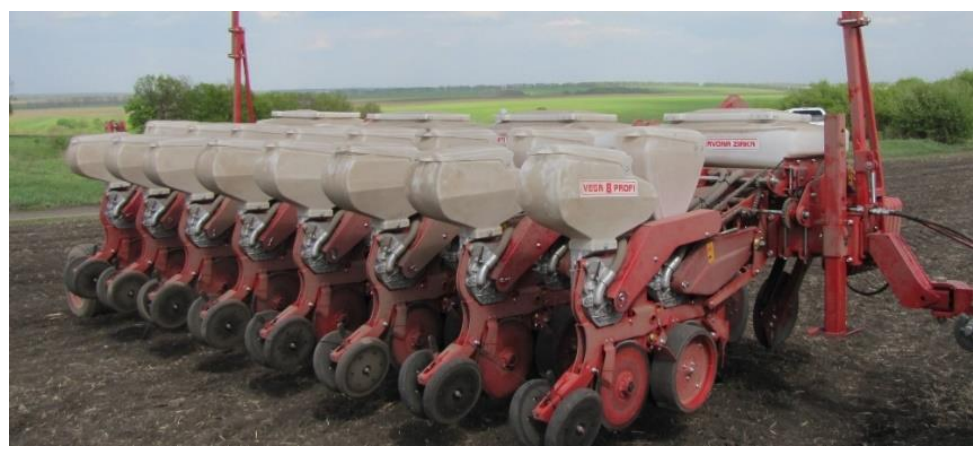

Fig. 1. General view of the seeder "Vega-8w Profi" prototype

This specialized seeder Vega- $8 \mathrm{w}$ is developed on the basis of a serial pneumatic seeder. Unlike a serial one, the specialized seeder "Vega-8w Profi" for mixed sowing of forage crops has the original dual seed distributor (Fig. 2) on each of 8 lines that allows you to sow two crops in each row, and if necessary, sow eight pairs of different crops within the coverage of the seeder. The specialized seeder is equipped with a system for monitoring the sowing process on each of the eight rows, and devices that improve the condition of the soil and roll the sown rows [patent 12].

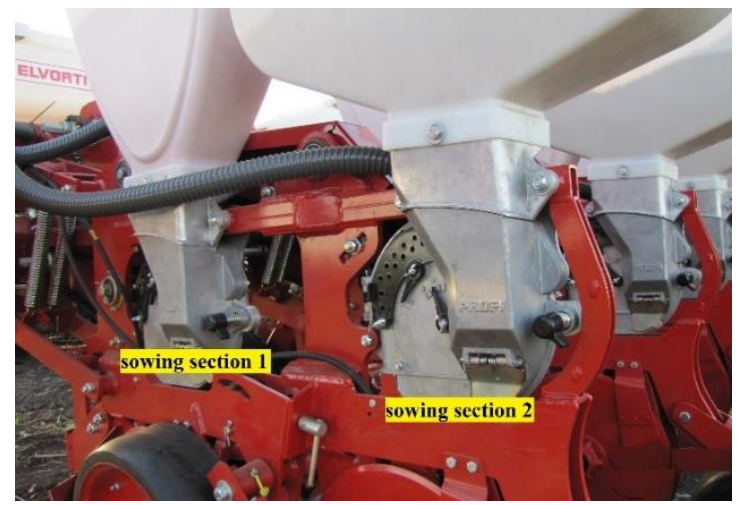

Fig. 2. Dual seed distributor of the seeder "Vega-8w Profi" prototype

In order to identify the effectiveness of this seeder, in spring and summer, the leading departments of KhNTUA: "Optimization of technological systems" and "Agricultural Machinery" conducted a 
research in accordance with the developed program and methodology, which included determining the quality parameters of the seeder for mixed sowing of corn and soybean crops. The experiments were conducted in the production conditions of the state farm "Experimental State Farm "Kutuzivka" of the Institute of Agriculture of the North-East of the NAAS, Ukraine on a field of 94 hectares, the predecessor being corn and grain. The indicators characterizing the state of the field during sowing are presented in Table 1.

Indicators of the condition of the field where mixed sowing of corn and soybean

Table 1 was carried out with the seeder "Vega-8w Profi"

\begin{tabular}{|c|c|}
\hline \multicolumn{1}{|c|}{ Name of indicators } & Value of indicators \\
\hline Moisture of the soil in the layers: \\
\hline $0-5 \mathrm{~cm}$ & $24.0 \%$ \\
\hline $5-10 \mathrm{~cm}$ & $26.2 \%$ \\
\hline $10-15 \mathrm{~cm}$ & $28.0 \%$ \\
\hline \multicolumn{2}{|c|}{ Hardness of the soil in the layers: } \\
\hline $0-5 \mathrm{~cm}$ & $1.1 \mathrm{MPa}$ \\
\hline $5-10 \mathrm{~cm}$ & $1.4 \mathrm{MPa}$ \\
\hline $10-15 \mathrm{~cm} \quad 1.7 \mathrm{MPa}$ \\
\hline \multicolumn{2}{|c|}{ The depth pre-sowing tillage: } \\
\hline - average X; & $7.0 \mathrm{~cm}$ \\
\hline - minimal; & $2.0 \mathrm{~cm}$ \\
\hline - maximal; & $15.0 \mathrm{~cm}$ \\
\hline Root mean square deviation $(\sigma)$ & $\pm 3.3 \mathrm{~cm}$ \\
\hline
\end{tabular}

As the analysis of the table data shows, the soil moisture in the layers of seed bedding (from 0 to $10 \mathrm{~cm}$ ) was $24.0-26.2 \%$, which, on the one hand, is positive, but, on the other hand, could be the reason for clogging of the ploughshares. The hardness of the soil, which was 1.1-1.4 MPa, was characteristic of the condition of the soil after its pre-sowing tillage. The average depth of pre-sowing tillage was $7.0 \mathrm{~cm}$, which corresponded to the optimal conditions for sowing both crops.

\section{Results and discussion}

According to our own method and the method [13], the research was carried out on mixed sowing of corn and soybeans, which were sown with the machine as part of the experimental seeder "Vega- $8 \mathrm{w}$ Profi" and the tractor "Belarus-1221", using high-yielding varieties of corn "Solominskaya 298 SR" and soybeans "Khutoryanochka", which had shown high laboratory germination of seeds: $98 \%$ and 94\%, respectively. The speed of the seeding machine was in the range from 6 to $11 \mathrm{~km} \cdot \mathrm{h}^{-1}$. In the course of the research experimental plots were marked, on which the so-called single crop sowing was performed [14], this is when one of the two crops was sown by the method of disabling the drive of seed distributor. The purpose of such method of sowing was to obtain a result on the biological yield of these crops, which are sown separately from each other, but will retain the same conditions as the mixed sown crops. The evaluation of sowing quality was determined by several indicators [15] presented in Table 2.

Table 2

Indicators of quality of sowing with the experimental seeder "Vega-8w Profi"

\begin{tabular}{|c|c|c|c|}
\hline \multirow[t]{2}{*}{ Name of indicators } & \multirow{2}{*}{$\begin{array}{c}\text { Units of } \\
\text { measurement }\end{array}$} & \multicolumn{2}{|c|}{ Value of indicators } \\
\hline & & mixed seeding & single seeding \\
\hline $\begin{array}{c}\text { Standard seeding rate: } \\
\text { corn } \\
\text { soybean }\end{array}$ & $\begin{array}{l}\text { thousand } \\
\text { plants } \cdot \text { ha }^{-1}\end{array}$ & $\begin{array}{l}120.8 \\
260.0\end{array}$ & $\begin{array}{l}120.5 \\
260.0\end{array}$ \\
\hline Operating speed & $\mathrm{km} \cdot \mathrm{h}^{-1}$ & $8.5-9.5$ & $8.5-9.5$ \\
\hline $\begin{array}{l}\text { seeding depth: } \\
\text { corn } \\
\text { soybean }\end{array}$ & $\begin{array}{l}\mathrm{cm} \\
\mathrm{cm}\end{array}$ & $\begin{array}{l}6.5 \\
6.6\end{array}$ & $\begin{array}{l}5.8 \\
6.6\end{array}$ \\
\hline
\end{tabular}


Table 2 (continued)

\begin{tabular}{|c|c|c|c|}
\hline \multirow[t]{2}{*}{ Name of indicators } & \multirow{2}{*}{$\begin{array}{c}\text { Units of } \\
\text { measurement }\end{array}$} & \multicolumn{2}{|c|}{ Value of indicators } \\
\hline & & mixed seeding & single seeding \\
\hline $\begin{array}{l}\text { Density of the seeding during full } \\
\text { germination: } \\
\text { corn } \\
\text { soybean }\end{array}$ & $\begin{array}{l}\text { thousand } \\
\text { plants } \cdot \text { ha }^{-1}\end{array}$ & $\begin{array}{c}110 \\
211.6\end{array}$ & $\begin{array}{c}110 \\
214.5\end{array}$ \\
\hline $\begin{array}{l}\text { Distribution of plants along the row; } \\
\text { average distance between the plants: } \\
\text { corn } \\
\text { soybean }\end{array}$ & $\begin{array}{l}\mathrm{cm} \\
\mathrm{cm}\end{array}$ & $\begin{array}{l}13.5 \\
6.7\end{array}$ & $\begin{array}{c}12.2 \\
6.6\end{array}$ \\
\hline
\end{tabular}

During the field research, the effect of changing the sowing rate on the seeding rate was determined. The final result of sowing - field germination - was taken as a criterion for quality assessment. The results of the research were obtained, when the seeder speed changed from 4.70 to $10.0 \mathrm{~km} \cdot \mathrm{h}^{-1}$, and accordingly the field germination and seeding rate did not change, which confirms the ability of the experimental seeder to ensure seed stability in this speed range.

The results of mixed sowing of fodder crops of corn and soybeans are shown in Fig. 3-5.
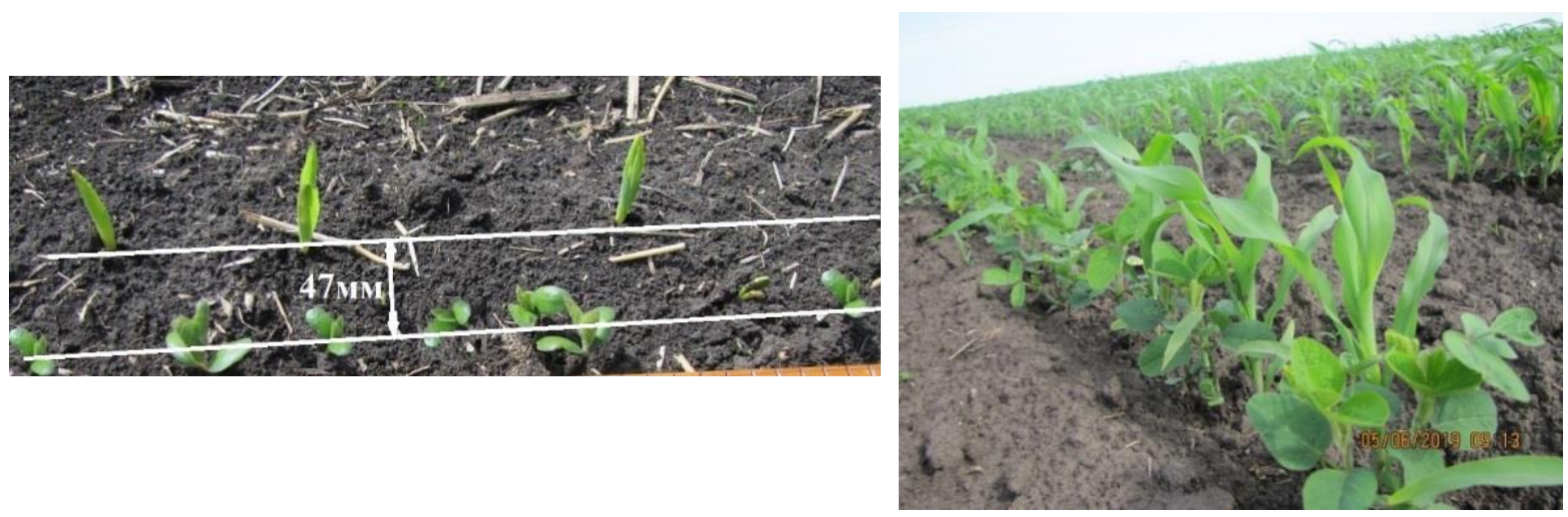

Fig. 3. Germination of the co-cultivated crops

Fig. 4. Vegetative growth of the cocultivated crops

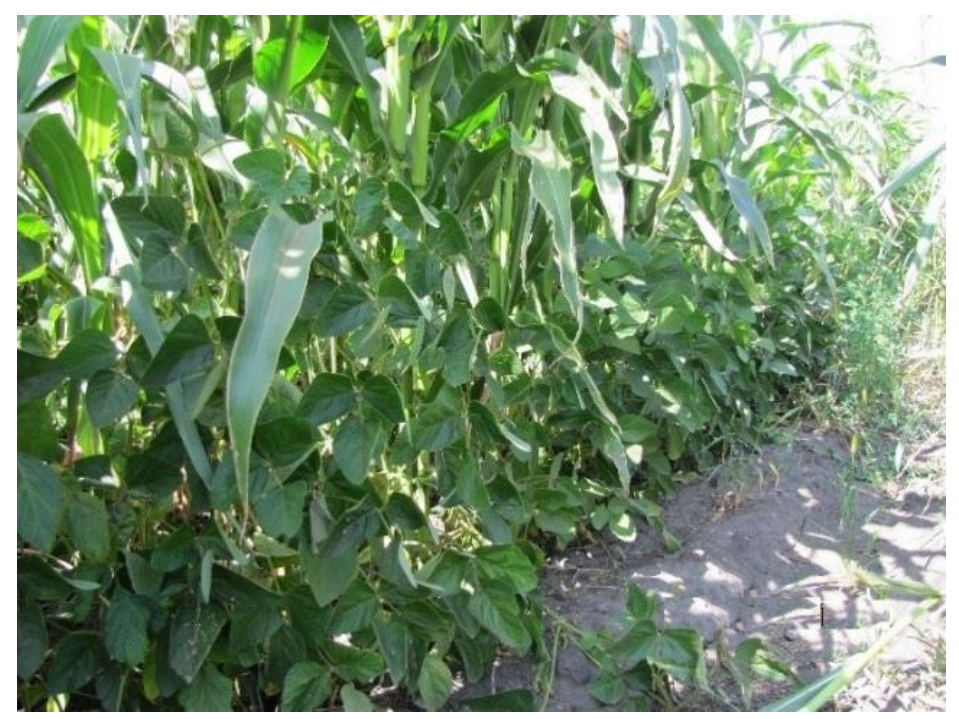

Fig. 5. State of co-cultivated corn and soybean crops before harvest

The studies on the technology of mixed growing of corn and soybeans allowed obtaining biological yields in the experimental plots, where single crop sowing was carried out and in the main field, where mixed crops grew in the same row with an offset of $47 \mathrm{~mm}$. The results are presented in Table 3. 
Results of the yield of the co-cultivated fodder crops of corn and soybeans before harvest

Table 3

\begin{tabular}{|l|c|c|}
\hline \multirow{2}{*}{$\begin{array}{c}\text { Indicators of } \\
\text { yield }\end{array}$} & \multicolumn{2}{|c|}{ Value of indicators } \\
\cline { 2 - 3 } & mixed seeding, $\mathbf{t} \cdot \mathbf{h a}^{\mathbf{- 1}}$ & single seeding, $\mathbf{t} \cdot \mathbf{h a}^{\mathbf{- 1}}$ \\
\hline - average & 49.4 & 51.65 \\
\hline - minimal & 34.35 & 38.7 \\
\hline - maximal & 64.45 & 64.6 \\
\hline \multicolumn{3}{|c|}{ Soybean } \\
\hline - average & 7.4 & 21.47 \\
\hline - minimal & 3.5 & 18.35 \\
\hline - maximal & 11.3 & 24.6 \\
\hline
\end{tabular}

The results shown in Table 3 show that the yield of single seeding of each crop separately is higher than the same crops, but in co-sowing, but the total yield of silage exceeds that of single crops.

Continuing the study, we moved on to the next stage of feed production [16;17; 18]. From cocultivated fodder crops of corn and soybeans [19] we obtained results on feeding dairy cows on silage only from pure corn and silage from mixed crops. The result is presented in Table 4.

Table 4

Information on the productivity of cows with the use of corn and corn-soybean silage at the breeding plant "Experimental farm of the Institute of Agriculture of the North-East, NAAS of Ukraine", Sumy region

\begin{tabular}{|c|c|c|c|}
\hline \multirow{2}{*}{\multicolumn{2}{|c|}{ Parameter }} & \multicolumn{2}{|c|}{ silage } \\
\hline & & corn & corn and soybean \\
\hline \multirow{3}{*}{ Number of cows } & October & \multicolumn{2}{|c|}{350} \\
\hline & November & \multicolumn{2}{|c|}{350} \\
\hline & December & \multicolumn{2}{|c|}{350} \\
\hline \multirow{3}{*}{ Milk yields, $\mathrm{kg} \cdot$ year $^{-1}$} & October & 5425 & 5845 \\
\hline & November & 6020 & 6300 \\
\hline & December & 5880 & 6125 \\
\hline \multirow{2}{*}{ Milk quality using silage } & $\%$ of fat & 3.6 & 3.8 \\
\hline & $\%$ of protein & 3.0 & 3.2 \\
\hline \multirow{3}{*}{ Average content, $\mathrm{g} \cdot \mathrm{kg}^{-1}$} & fat & 1.29 & 1.05 \\
\hline & protein & 3.09 & 3.36 \\
\hline & carotene & 20 & 37 \\
\hline \multirow{3}{*}{$\begin{array}{l}\text { Average daily weight gains of } \\
\text { heifers using silage, } g\end{array}$} & October & 628 & 677 \\
\hline & November & 830 & 933 \\
\hline & December & 644 & 758 \\
\hline
\end{tabular}

The productivity indicators of cows given in Table 4 prove a positive result of the efficiency of mixed sowing of fodder crops of corn and soybeans [20]. The research does not end there, the issues of quality selection of corn and soybean varieties for co-cultivation remain open, and the ratio of corn and soybeans, as well as other crops in the quantitative composition of forage crops.

\section{Conclusions}

1. The greatest effect is given by mixed sowing of two crops in one row with shift on $47 \mathrm{~mm}$ one crop from another.

2. The specialized seeder for the technology of mixed sowing of fodder crops, developed as a result of joint work of the scientists of KhNTUA and specialists of PJSC "Elvorti", provides stable implementation of the technological process of co-sowing of two fodder crops in one row.

3. The studies of sowing quality at different speeds of the specialized seeder "Vega- $8 \mathrm{w}$ Profi" for mixed sowing of grain and soybeans showed that, at this stage, it provides a satisfactory quality of sowing in the speed range of $4.7-12.0 \mathrm{~km} \cdot \mathrm{h}^{-1}$. 
4. The results of comparing the biological yield of fodder crops of corn and soybeans, sown together, show that single-seeded crops have higher yields than co-sown ones.

5. The effectiveness of the feed product obtained from co-cultivated fodder crops of corn and soybeans is expressed in increasing the milk yield of cows and at the same time in improving the quality of milk, with increased fat and protein content.

\section{References}

[1] Melnyk V.I. The concept of advanced development of equipment and technologies in the agroindustrial complex. Scientific journal "Engineering of nature management". 2018. No. 1(9), 2018, pp. 24-35.) (In Ukrainian).

[2] Melnyk V.I. The evolution of agricultural systems - loofing ahead. Scientific and practical journal 'Agriculture and plant protection'. 2015. No. 5(102), pp. 3-8. (In Ukrainian).

[3] Petrichenko V.F, Zadorozhna I.S. Development of field feed production in Ukraine. Bulletin of Agricultural Science. April 2010. pp. 65-67. (In Ukrainian).

[4] Yamkova B. Co-cultivation of crops of corn and soybeans. The main journal on agribusiness. [online] [14.06.2013] Available at: http://propozitsiya.com/ua/ viroshchuvannya-sumisnih-posivivkukurudzi-ta-soyi

[5] Kuzmenko O. S. Catch cropping and mixed sowing in Ukraine. Kyiv: Vyscha Shkola, 1986. 175 p.

[6] Begay S.V. Catch cropping and mixed sowing. Kyiv: Urozhai, 198057 p.

[7] Borst H. L., Park, G. B. Experiments with growing corn and soy bean in combination. Ohio Agr. Exp. Sta. Bull, 1992, 513 p.

[8] Grookston, R. K., Hill, D. S. Grain yields and land equivalent ratios from inter cropping corn and soybeans in Minnesota. Agron, 71, 1979, pp. 41-44.

[9] Singh, C. M. Nitrogen acculation in maize inter cropped with grain legumes under varyind levels of nitrogen. Food Farms Agr, 10, 1979, pp. 314-315.

[10] Seeder of precise seeding of two-row sowing MS TWIN ROW 8100 [online] [14.03.2021] Available at: https://agrobiz.net/civalka-tochnogo-visivu-dvohryadkovogo-posivu-ms-twin-row8100.html

[11] Welcome to Great Plains Manufacturing's Corporate Home [online] [14.03.2021] Available at: www.greatplainsmfg.com

[12] Patent for utility model 134659134659, Ukraine, IPK (2019.01) A01C7/00, A01C1/00, A01B49/04/2006.01 Section of a row seeder for mixed sowing/VI Melnik, M.V. Bakum, V.I. Pastukhov, R.V. Kirichenko, M.O. Tsyganenko, D.V. Krochnal. Declared 03.01.2019; Published May 27, 2019, Bul. No.10. 2019.

[13] Доспехов Б. Методика полевого опыта (Methodology of a field experiment). Moscow, 2012, 352 p. (In Russian);

[14] Melnyk V.I, etc. Co-cultivation of fodder crops. Bulletin of KhNTUA 'Mechanization of agricultural production'. Issue 199. Kharkiv. 2019. pp. 95-102.

[15] Mironenko V. The seeder is evaluated on germination. Journal Agronomist [online] [17.03.2021] Available at: https://www.poettinger.at/uk_ua/Newsroom

[16] Андрущак В. и др. Профессиональное кормопроизводство: сенаж, силос, сено (Professional feed production: haylage, silage, hay). - Kyiv: Grain, 2012. - 168 p. (In Russian).

[17] Sergeya N. High-quality roughage - the key to high milk yields. APC Technology and Technologies, 2013, 6 (45),pp. 18-19. (In Ukrainian).

[18] Rules for grown soybean-maize cropping system in Midwestern Brazil: Food production and economic profits Battisti, R. , Ferreira, M.D.P. , Tavares, É.B. (2020) Agricultural Systems

[19] Gnoyevoyi V.I. etc. Mixed sowing of corn and soybean seeds for silage according to the new technology. Interdepartmental thematic scientific collection 'Feed and feed production'. Issue. 86. Vinnytsia. 2018. - pp. 71-76.

[20] Melnik V.I. etc. The results of research work of a prototype of a specialized seed drill for joint crops of forage crops. Scientific journal "Engineering of nature management". 2019. No. 3(13), pp. 35 42.) (In Ukrainian). 